\title{
Mortality in non-elderly septic patients was increased with hypothermia and decreased with fever while mortality in elderly patients was not associated with body temperature: beware of some confounders!
}

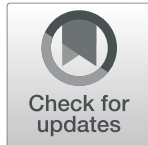

\author{
Patrick M. Honore*, Leonel Barreto Gutierrez, Luc Kugener, Sebastien Redant, Rachid Attou, Andrea Gallerani and \\ David De Bels
}

We read with great interest the recent article by Shimazui et al. who concluded that in septic patients, mortality in non-elderly patients was increased with hypothermia and decreased with fever, while mortality in elderly patients was not associated with body temperature (BT) [1]. We would like to make some comments. As was alluded to by the authors themselves, BT measurement can be potentially confounded by various factors, including variation in the site of temperature measurement and whether or not patients receive antipyretics or targeted temperature management [1]. Nearly half of critically ill patients, especially those with septic shock, have or develop acute kidney injury (AKI) and 20-25\% need renal replacement therapy (RRT) within the first week of their stay [2]. In the study of Shimazui et al., more than $60 \%$ of patients in both groups were in septic shock [1]. So, potentially, a third of patients may have had AKI, with $15 \%$ receiving continuous RRT (CRRT). CRRT is well known for blunting temperature in septic shock patients [3]. Moreover, in the elderly population, the risk of developing AKI is increased by age-related physiological changes, lower renal reserves, and multiple comorbidities that render them more susceptible to acute renal impairment [4]. In addition, elderly patients typically take more medications and undergo more procedures, which may endanger their renal function [4]. Hence, AKI is generally more common among the elderly [4]. A recent study found that frailty was a predictor for the development of AKI, increasing the likelihood by more than three times [5]. Therefore, it is a possibility that there were more patients with artificial hypothermia (below $36^{\circ} \mathrm{C}$ ) as a result of RRT in the elderly group of Shimazui et al., introducing a confounder to the study [1]. Unfortunately, data regarding AKI and RRT have not been reported in the study of Shimazui et al., so we are unable to confirm our hypothesis.

This comment refers to the article available at https://doi.org/10.1186/ s13054-020-02976-6.

* Correspondence: Patrick.Honore@CHU-Brugmann.be

ICU Department, Centre Hospitalier Universitaire Brugmann-Brugmann

University Hospital, Place Van Gehuchtenplein, 4, 1020 Brussels, Belgium

C C The Author(s). 2020 Open Access This article is licensed under a Creative Commons Attribution 4.0 International License, which permits use, sharing, adaptation, distribution and reproduction in any medium or format, as long as you give appropriate credit to the original author(s) and the source, provide a link to the Creative Commons licence, and indicate if changes were made. The images or other third party material in this article are included in the article's Creative Commons licence, unless indicated otherwise in a credit line to the material. If material is not included in the article's Creative Commons licence and your intended use is not permitted by statutory regulation or exceeds the permitted use, you will need to obtain permission directly from the copyright holder. To view a copy of this licence, visit http://creativecommons.org/licenses/by/4.0/ The Creative Commons Public Domain Dedication waiver (http://creativecommons.org/publicdomain/zero/1.0/) applies to the data made available in this article, unless otherwise stated in a credit line to the data. 


\section{Authors' response}

Takashi Shimazui, Taka-aki Nakada and Taku Oshima

Department of Emergency and Critical Care Medicine, Chiba University Graduate School of Medicine, 1-8-1

Inohana, Chuo, Chiba 260-8677, Japan

We read with great interest the letter by Honore et al., concerning the potential confounding effect of continuous replacement therapy (CRRT) on body temperature (BT) measurement. The generally higher risk of developing acute kidney injury (AKI) in elderly patients might also influence the results.

To evaluate the impact of CRRT on our primary finding [1], we added analyses focused on AKI on admission and CRRT within the first $24 \mathrm{~h}$ from admission in the discovery cohort. According to the data availability, AKI was diagnosed based on the KDIGO criteria with some modification [6]: urine output in the first $24 \mathrm{~h}<0.5 \mathrm{~mL} / \mathrm{kg}$, or serum creatinine levels on admission $\geq 0.3 \mathrm{mg} / \mathrm{dL}$ than baseline creatinine. Baseline creatinine was calculated using the Modification of Diet in Renal Disease (MDRD) study equation modified for the Japanese population [7], assuming an estimated glomerular filtration rate (eGFR) of $75 \mathrm{~mL} /$ $\mathrm{min} / 1.73 \mathrm{~m}^{2}$ [6].

As Honore et al. have pointed out, the morbidity of AKI on admission was significantly higher in elderly patients compared to non-elderly patients (elderly $82.5 \%$, nonelderly $73.8 \%, P=0.0005$ [chi-square test]). However, nonelderly patients were more frequently initiated on CRRT within first $24 \mathrm{~h}$ compared to elderly patients (elderly $17.2 \%$, non-elderly $27.0 \%, P<0.0001$ ); non-elderly patients had higher chance of temperature alteration by CRRT. In addition, adding "CRRT" as covariates including previously reported analysis in the Cox regression for the hazard of death over 90 days by the BT adjusted with potential imbalances of age (per year), sex, chronic steroid use, and APACHE II score yielded results similar to the primary findings (non-elderly, BT $<36^{\circ} \mathrm{C}$ and $>38.3^{\circ} \mathrm{C}$, $P=0.024$ and $P=0.14$, adjusted hazard ratio 1.70 and $0.73,95 \%$ CI $1.07-2.71$ and $0.48-1.10$; elderly, BT $<36^{\circ} \mathrm{C}$ and $>38.3^{\circ} \mathrm{C}, P=0.091$ and $P=0.87$, adjusted hazard ratio 0.62 and $0.96,95 \%$ CI $0.36-1.08$ and $0.63-1.47$ ).

According to these results, we conclude that the BT, especially hypothermia, may be associated with mortality in non-elderly septic patients including those treated with CRRT, while the association between BT and mortality remains inconsistent in elderly septic patients even after adjusting the CRRT effects.

\section{Abbreviations}

BT: Body temperature; AKI: Acute kidney injury; RRT: Renal replacement therapy; CRRT: Continuous renal replacement therapy

\section{Acknowledgements}

None.

\section{Authors' contributions}

$\mathrm{PMH}, \mathrm{SR}$, and DDB designed the paper. All authors participated in drafting and reviewing. All authors read and approved the final version of the manuscript.

\section{Funding}

None.

Availability of data and materials

Not applicable.

Ethics approval and consent to participate

Not applicable.

\section{Consent for publication}

Not applicable.

\section{Competing interests}

The authors declare to have no competing interests.

Received: 10 September 2020 Accepted: 30 September 2020 Published online: 13 October 2020

\section{References}

1. Shimazui T, Nakada TA, Walley KR, et al. Significance of body temperature in elderly patients with sepsis. Crit Care. 2020;24(1):387. https://doi.org/10. 1186/s13054-020-02976-6.

2. Peters $E$, Antonelli $M$, Wittebole $X$, Nanchal $R$, François $B$, Sakr $Y$, et al. A worldwide multicentre evaluation of the influence of deterioration or improvement of acute kidney injury on clinical outcome in critically ill patients with and without sepsis at ICU admission: results from the intensive care over nations audit. Crit Care. 2018;22(1):188. https://doi.org/ 10.1186/s13054-018-2112-z

3. Yagi N, Leblanc M, Sakai K, Wright EJ, Paganini EP. Cooling effect of continuous renal replacement therapy in critically ill patients. Am J Kidney Dis. 1998;32(6):1023-30. https://doi.org/10.1016/s0272-6386(98)70078-2.

4. Medina-Liabres KRP, Kim S. Continuous renal replacement therapy in elderly with acute kidney injury. Korean J Intern Med. 2020;35(2):284-294. [published correction appears in Korean J Intern Med. 2020 May;35(3):740] doi:https://doi.org/10.3904/kjim.2019.431.

5. Baek SH, Lee SW, Kim SW, et al. Frailty as a predictor of acute kidney injury in hospitalized elderly patients: a single center, Retrospective cohort study. PLoS One. 2016;11(6):e0156444. https://doi.org/10.1371/ journal.pone.0156444.

6. Kidney Disease: Improving Global Outcomes (KDIGO) Acute Kidney Injury Work Group. KDIGO clinical practice guideline for acute kidney injury. Kidney Int Suppl. 2012:2:1-138.

7. Matsuo S, Imai E, Horio M, Yasuda Y, Tomita K, Nitta K, et al. Revised equations for estimated GFR from serum creatinine in Japan. Am J Kidney Dis. 2009:53:982-92.

\section{Publisher's Note}

Springer Nature remains neutral with regard to jurisdictional claims in published maps and institutional affiliations. 